\title{
Spillover effects of innovation and entrepreneurial activity on income inequality in developing countries: A spatial panel approach
}

\section{Lawrence Adu Asamoah}

Department of Economics, University of Insubria, Italy

\section{Correspondence}

Lawrence Adu Asamoah, Department of Economics, University of Insubria, Via Monte Generoso, 71, Varese 21100, Italy.

Email: laduasamoah@uninsubria.it

\section{Francesco Figari | Andrea Vezzulli}


solution to increase entrepreneurial activities while reducing inequality is for governments in developing countries to offer various schemes targeted at the poor, especially finance.

\section{KEYWORDS}

developing economies, entrepreneurial activity, income inequality, innovation, microeconomics, spatial regression

\section{JEL CLASSIFICATION}

O15; O30; L26

\section{1 | INTRODUCTION}

Sustained economic growth remains a critical pathway out of poverty and a core driver of economic development. Yet, evidence shows that it is not enough as an impetus for equal wealth distribution. The World Inequality Report in 2018 showed a marked rise in the Gini coefficient, income inequality, by more than 10\% over the past decades. Incomes of the top $10 \%$ accounted for $61 \%$ of the share of national income in the Middle East, $55 \%$ in Sub-Saharan Africa, and 37\% in Europe (Alvaredo et al., 2018). These trends in income inequality have persisted alongside global trends in economic growth (Alvaredo et al., 2018; Piketty, 2015), enterprise creation, and technical change (Piketty, 2015). These key drivers of economic growth have been generally accused to have induced unequal income distribution and heightened poverty as an outgrowth of the capitalist system. Evidence suggests that efficiency in innovation has promoted entrepreneurial successes and wage polarization at a much larger scale than before and therefore produced larger swings in the distribution of income (Frey \& Osborne, 2017; Packard \& Bylund, 2018). Yet nowadays, there is general support for innovation and entrepreneurship. Governments and policy experts across the world are focused on promoting enterprise creation and technological innovation to achieve profitable and sustained growth.

In this context, innovation and entrepreneurship are considered as agents of change, and income inequality is the reward for this innovation and risk-taking (entrepreneurship). Innovation and entrepreneurship drive productivity, and in turn, productivity drives the flow of real income (Aghion et al., 2019; Frey \& Osborne, 2017; Halvarsson et al., 2018; Piketty, 2015). While economists have demonstrated the relevance of innovation as a key element of economic progress, it is also imperative to stress the importance of the person who incorporates the innovation into the production process. This is because someone has to take the risk while making the decision to incorporate innovation in the firm. This person is the entrepreneur, and his activity has a positive effect on income distribution. The incentive to engage in enterprise creation is expected to be influenced by an array of factors that may inform the intentions, motivation, and actions of an entrepreneur, the paramount of which is profit maximization, which has been argued to produce larger swings in income of entrepreneurs (Acs et al., 2009). For example, disequilibrating entrepreneurs may support mechanisms that limit entry of new firms and also promote rent-seeking to preserve market power (Quadrini, 2000, 2009). While for many years scholars have almost uncritically (save for few) considered innovation and entrepreneurship as means to economic growth, it is only in recent times that evidence have shown that entrepreneurship and innovation can under certain conditions exacerbate injustice, by creating imbalances in income distribution (income inequality), and deepen poverty (Cozzens et al., 2010; Cozzens \& Kaplinsky, 2009; Piketty, 2015).

The geographical dimension has received little attention (with a few exceptions). Ragoubi and El Harbi (2018) used spatial regression analysis by combining global competitiveness variables to show that business creation 
represents a strong territorial dimension in the analysis of the demographic disparities of income distribution. Also, Aghion et al. (2019) employed a Schumpeterian model in a nonspatial analysis to emphasize that geographical location positively influences the impact of innovation on income distribution in the United States. In addition, the territorial flow of innovation has been used to explain demographic disparities of income inequality and poverty (Lee \& Rodríguez-Pose, 2013), and cross-border entrepreneurship (Mohamad et al., 2021). Aghion et al. (2019) and Lee and Rodríguez-Pose (2013), though emphasizing the effect of spatial dimension of innovation and entrepreneurship on income inequality, do not consider the spatial spillover process using a spatial econometric technique that accounts for spatial clustering in a heterogeneous way. These studies of Aghion et al. (2019) and Lee and Rodríguez-Pose (2013) sought to identify the linkages between innovation and income inequality but not to analyze the spatial dimension. The current study presents an extension to these studies, but with major focus on developing countries. Second, our study provides a new perspective on the impact of innovation and entrepreneurship on income inequality by giving specific attention to how geographical proximity deepens the impact of knowledge spillovers on the distribution of income. Indeed, as shown by Tobler (1970), Sampson et al. (1999) and Ragoubi and El Harbi (2018), neighborhood effects are the strongest influences on the patterns of socioeconomic conditions. As such, beyond internal characteristics of a country, trade agreements, multinational corporations, and joint ventures, geographical proximity has a powerful influence on income distribution such that one local trade member/subsidiary's decision is highly dependent on its neighbor's decision or behavior. Therefore, it is important to account for spatial effects in income distribution patterns because, if such effects exist but are not accounted for in the model, parameter estimates may be biased and inconsistent (Anselin, 1988). Third, the spatial econometric tool, which is more robust to spatial dependence and unknown country heterogeneity issues, is applied in this study.

The rest of the study proceeds as follows: a review of related literature in section 2 and a discussion of methodology in section 3. In section 4, we present our data analysis and discussion, and finally, section 5 concludes.

\section{2 | REVIEW OF RELATED LITERATURE}

\subsection{Innovation and income inequality nexus}

The concept of innovation is not new in economics. Innovation is the process of creating new technologies and using them in the economy. Economists usually use a broad definition of technology, so when they talk about innovation, economists do not think just about new machines or inventions but any new ways of doing things (including knowledge). For instance, when classical economists described market behavior and mechanical advances in economic growth, they meant innovation (Galindo \& Méndez-Picazo, 2013). Also, Adam Smith in the 'Wealth of Nations', advanced that one way for firms to intensify competitive advantage for their products is to introduce innovations in the productive process. From a modern economic perspective, technological diffusion and the catch-up process (innovation) were the main drivers of growth (Aghion \& Howitt, 1998; Lucas, 1988; Romer, 1990). A large body of empirical works have evolved from this focus on technological progress and innovation. These studies have established that the level of innovation is a sine qua non condition for economic performance, particularly at the firm and industry level. These can either be product innovation or process innovation. The Oslo Manual also acknowledges that innovation is not restricted to single discrete changes, but may also consist of a series of incremental changes, provided these changes together amount to a substantial improvement in a product or production method (Bloch, 2007). Although product innovation is minimal comparatively in middle-and-low-income countries, process innovation is widespread (Wong et al., 2005). Several studies have investigated their implications on growth, but the same conclusion cannot be drawn for income inequality because economic growth and income inequality are two different concepts. Researchers have not investigated innovation and income inequality in great detail, and they thus deserve attention in the context of middle-and-low-income countries. Evidence has shown that some of the 
channels through which innovation may affect income inequality is either via knowledge spillovers between parent and subsidiary relationship or via property rights that restrict copying or imitation.

Prior studies, including Aghion et al. (2019), Antonelli and Gehringer (2017), Breau et al. (2014), Lee and Rodríguez-Pose (2013), Acemoglu and Autor (2011) and Lee (2011), examined the innovation-inequality debate and concluded that intellectual property rights, skilled-biased technological changes, and capital gains (mark-up) are some of the drivers of modern-day income inequality. In the spirit of the Schumpeterian growth model, Aghion et al. (2019) examined the linkage between innovation, top-income inequality, and social mobility in the United States, employing instrumental variable analysis. The authors showed that innovation (measured with patents and citations) contributes positively to top-income inequality, but not to broad measures of inequality. They found that the correlation between entrant innovation and top-income inequality is lower in states with higher lobbying intensity. The limitation of this study is that they do not build on the spatial econometric model to deal with spatial clustering and heterogeneity of innovation. Antonelli and Gehringer (2017) investigated the role of technological change on the levels of income inequality in 36 OECD countries over the period 1996-2011. Breau et al. (2014) employed census data of Canada over the period 1996-2006 to examine the relationship between innovation and wage inequality among Canadian cities. Their findings revealed a positive effect of innovation on inequality after controlling for other possible factors that may determine income inequality. Lee (2011) also assessed the innovation-inequality nexus across a panel of European economies from the European Community Household Panel and the Eurostat Regio database over the period 1996-2001. Using fixed-effects panel regression methods, the author showed a positive effect of innovation on income inequality. Lee further revealed that the nexus was robust when patent count was used as a measure of innovation. Buttressing these results, Lee and Rodríguez-Pose (2013) confirmed a positive innovation-inequality association in Europe after extending the analysis to 80 US cities, using microdata from the IPUMS Current Population Survey. Evidence of less-flexible labor market conditions and lower levels of migration were seen to drive the nexus between innovation and inequality in Europe compared with the United States. Rodríguez-Pose and Crescenzi (2008) analyzed the link between investment in research and development (R\&D), patents, and economic growth in Europe. They find that R\&D investment is more conducive to economic growth because of its impact on performance in both local and neighboring regions. In the case of developing countries, Adams (2008) investigated the effects of globalization and intellectual property rights on income inequality for 62 developing countries from 1985 to 2001 using seemingly unrelated regression estimations. The findings demonstrated that strengthening patent protection indeed impacted positively on income inequality. Seo et al. (2020) tested the impact of income inequality on growth of 43 countries from 1991 to 2014 using three-stage least squares (3SLS) regression. They found a negative relationship between inequality and investment but did not find correlation between technological innovation and income inequality. Given that institutional quality and governance play an important role in economic development (Azman-Saini \& Hook Law, 2012), some degree of influence may govern the relationship between innovation and income inequality. From the investor perspective, profitability is the key factor that motivates the creditor to finance an innovation. And since the rich already have the resources, they will have the upper hand in securing finance using their wealth as collateral. We hypothesize:

Hypothesis 1. Higher rate of innovation increases income inequality.

\section{2 $\quad$ Entrepreneurship and income inequality nexus}

Entrepreneurship is the creation or extraction of value (Gaddefors \& Anderson, 2017). Entrepreneurship can therefore be seen as the capacity and willingness to develop, organize, and manage the activity of setting up a business in the hope of profit. In the field of economics, the term entrepreneur is used for an entity who has the ability to translate inventions or technologies into products and services (Acs, 2006). In this sense, entrepreneurship describes activities 
on the part of both established firms and new businesses. According to Kirzner, entrepreneurship consists of competitive behaviors that drive market process. This includes new firm entry (start-ups) or firm creation (self-employment). More recently, scholars have begun to re-examine the effect of the decisions of profit-maximizing agents (entrepreneurs) and how their behavior influence both growth and income inequality. In the entrepreneurship literature, Schumpeterian theories show the importance of entrepreneurial skills in economic transformation, and how an increase in the number of entrepreneurs leads to economic growth. These theories have led to a differentiation between entrepreneurs stemming from the lack of opportunities, and 'Schumpeterian' entrepreneurs who exploit some latent market opportunities (Stephens et al., 2013). Acs (2006) examined that 'entrepreneurship of necessity' may not necessarily translate into long-term economic growth compared with 'entrepreneurship of opportunity'. Yet, evidence from Stephens and Partridge (2011) showed stronger growth effects for opportunity entrepreneurship; they found that all forms of business creation are also associated with faster Appalachian employment growth. Scholars such as Lippmann et al. (2005) show that high income inequality occurs when necessity entrepreneurship becomes the only means for low-income individuals to maintain a certain level of well-being. Others including Alvaredo et al. (2017) and Piketty (2015) show that the existing income gap between the rich and the poor is due to the positive rate of return differentials between high-and low-income earners. Aghion et al. (2019) proposed an economic model based on Schumpeterian growth theory, which assumes that national income is divided between workers and entrepreneurs. The authors demonstrated that, in some economic sectors, such as the high-technological ones where capital gains (mark-up) exist, entrepreneurs and business leaders earn the largest share of the capital gains that accrue to the firms (Benos \& Tsiachtsiras, 2019), and this top income share increases when it is owned by all the entrepreneurs who have innovated successfully. Stephens et al. (2013) show that, regardless of the source, new business creation has three general effects on the economy: (i) the direct effect of creating jobs, (ii) the displacement effect (new businesses take jobs away from existing businesses), and (iii) the indirect (or spillover) effects on other businesses (Fritsch \& Mueller, 2004). The direct and indirect effects should increase total employment, and the displacement effects should lower total employment. Self-employment may have greater direct employment and income distributive effects owing to its more labor-intensive production. The indirect effects include the 'multiplier' effects caused by creation of subsidiary firms across countries. Likewise, intangible spillovers can arise when knowledge or business model created by one business 'spills over' into the immediate geographic region (Puga, 2010). In examining the impacts of entrepreneurs, it is important to recognize that, because the indirect effects may take time to materialize, the full effects from entrepreneurial development may only be realized over the longer term.

Empirically, studies including Cagetti and Nardi (2006), Halvarsson et al. (2018), Lewellyn (2018), Lippmann et al. (2005), and Ragoubi and El Harbi (2018), have examined the entrepreneurship-inequality linkages and established that the channel through which entrepreneurship may affect income inequality is via cross-border activities. Others are of the view that entrepreneurial activity is associated with upward social mobility. And aligned to this view is that employment-creating entrepreneurial activities that enhance opportunities for those at the bottom of the distribution improve the level of income dispersion (Bruton et al., 2013; Hathaway et al., 2013; Stangler \& Litan, 2009). Despite these arguments, others are of the view that the 'rich' people possess incentive mechanisms that limit access to resources, therefore increasing inequality (Acemoglu \& Johnson, 2005; Stiglitz, 2012). Employing data from the Global Entrepreneurship Monitor, Lippmann et al. (2005) examined the relationship between workforce income inequality and the rate of entrepreneurship. The authors found higher rates of entrepreneurship among economies with high income inequality. Their evidence was suggestive of the fact that structural factors, including the level of economic development, government policies, foreign direct investment, service sector growth, increasing labor market flexibility, wealth-transfer programs, and variation in worker unionization, have a significant influence on the entrepreneurship-income inequality relationship. Employing a system generalized method of moments (GMM) model with US state-level data, Atems and Shand (2018) examined the relationship between entrepreneurship and income inequality for the period from 1989 to 2013. Their findings showed a positive relationship between entrepreneurship and income inequality. In a fuzzy-set qualitative comparative analysis, Lewellyn (2018) found that high levels of both opportunity and necessity entrepreneurial activity are associated with income inequality in a certain context 
characterized by different institutional complementarity. ${ }^{1}$ Deutsch and Silber (2004) found that income inequality only increased with a rise in labor income share and declined with a fall in the share of entrepreneurial income, revealing a positive relationship between entrepreneurial income and income inequality. Aligned with this argument, Quadrini (2000) shows that entrepreneurship leads to a larger concentration of wealth due to a higher savings rate of entrepreneurs. In terms of low-and-middle-income countries, Ragoubi and El Harbi (2018) examined entrepreneurship and income inequality dynamics, using spatial panel data analysis for 33 high-income countries and 39 middle- and low-income countries over the period from 2004 to 2014. They found strong support for the negative spillover effect of income inequality on entrepreneurial activity in developing economies. Kimhi (2010) analyzed the impact of entrepreneurship on household income inequality in southern Ethiopia using inequality decomposition technique. The findings showed a decreasing effect of entrepreneurial income (income from self-employment) on household income inequality. However, this study fails to account for the spatial effect of entrepreneurship on household income inequality. Employing a two-stage least squares regression, Berkowitz and Jackson (2006) also show that higher rates of entry of new enterprises led to a more equitable distribution of income in Russia and Poland. Mohamad et al. (2021) examine the role of entrepreneurship on income inequality in developing countries using a sample of 47 countries over the period 2009-2017. Results from the generalized method of moments (GMM) show that increasing the level of entrepreneurship may decrease income inequality. Given the differing literature on the effect of entrepreneurial activities on high-income countries and low-and-middle-income countries, we address the following hypotheses:

Hypothesis 2. Entrepreneurial activities lead to higher income inequality in high-income countries.

Hypothesis 3. Entrepreneurial activities lead to lower income inequality in low- and middle-income countries.

\section{3 | RESEARCH METHOD}

\section{1 | Data}

In this paper, hypotheses are tested for two groups of countries. The list of countries is based on income. The study employs World Bank 2020 country classifications. ${ }^{2}$ Due to the low number of low-income countries, middle- and low-income countries are merged to form one set of countries called the middle-and-low-income countries (MLI), and the other group consists of the high-income countries (HI). The justification for this categorization is based on socioeconomic and political differences, hence eliminating to some extent the level of heterogeneity that otherwise might influence the models (see Ragoubi \& El Harbi, 2018). Thus, there are $64 \mathrm{MLI}$ countries and $25 \mathrm{HI}$ countries. Annual macroeconomic data covering the period 2000-2016 are used. The limiting constraint to our sample size was the availability of reliable data on the various indicators for the period of analysis, specifically income inequality, entrepreneurship indicator, and innovation. Our dependent variable is the Gini coefficient of disposable income, which measures the degree of within-country income inequality. The Gini coefficient of disposable income ranges between 0 and 1, with a value of 1 expressing maximum concentration of income, and 0 implying egalitarian distribution of income. The income inequality indicator is obtained from the Standardized World Income Inequality Database (SWIID v8.3). The study controls for the effect of real income (gross domestic product [GDP] per capita) and government spending, all extracted from the World Development Indicators (WDI). Capital per worker from Penn World Tables. Institutional quality, which is derived from the World Bank Governance Indicators (WBGI), is also controlled for in this study.

${ }^{1}$ Opportunity entrepreneur is defined to include individuals who start businesses to exploit a potential opportunity to increase their income and are mostly associated with more growth-oriented businesses. Necessity entrepreneurs, on the other hand, are individuals who are pushed into entrepreneurship out of necessity or seek only to maintain their income (Bosma \& Kelley, 2019).

${ }^{2}$ See Appendix B for list of countries. 
A key variable in this paper is innovation. This indicator has been measured using different indicators, including patent count, research and development (R\&D) as a share of GDP, product and process innovation, total factor productivity, and innovation in exports. In this study, an index of innovation is constructed following the works of Sinha and Alvarado (2020) and Usman and Hammar (2021). Principal component analysis (PCA) is used to transform three research and development $(R \& D)$ indicators into an index. These indicators are chosen because the progress of R\&D differs in each country, particularly in middle-and-low-income countries, and as such, using only one of the indicators of R\&D might not communicate the actual innovation of these countries. Missing values in any of the indicators were replaced with zero to prevent the PCA from generating missing scores. The indicators used include: (i) total number of patent applications (direct and Patent Cooperation Treaty [PCT] national phase entries), (ii) total number of trademark applications (direct and via the Madrid system), and (iii) total grants for direct applications (US dollars). All are based on equivalized counts. The model of the PCA is expressed as:

$$
\operatorname{Innov}_{\text {it }}=\theta_{0 i t}+\theta_{1 i t} \mathrm{PAT}_{i \mathrm{t}}+\theta_{2 \mathrm{it}} \mathrm{TMA}_{\mathrm{it}}+\theta_{3 \mathrm{it}} \mathrm{GRANT}_{\text {it }}+\mu_{\mathrm{it}},
$$

where Innov is innovation; PAT is patent applications; TMA is trademark applications; GRANT is total grants for direct applications. $\theta$ is the parameters. Statistics on the research and development indicators are downloaded from the World Intellectual Property Organization (WIPO).

Another relevant variable considered in this paper is entrepreneurship. Various scholars in the entrepreneurship literature have used unique indicators, including self-employment (Atems \& Shand, 2018; Halvarsson et al., 2018; Kimhi, 2010; Stephens et al., 2013; Stephens \& Partridge, 2011), the number of new business density (Ragoubi \& El Harbi, 2018), and total entrepreneurship activities (TEA) from Global Entrepreneurship Monitor (Galindo \& MéndezPicazo, 2013; Wennekers \& Thurik, 1999; Wong et al., 2005). The data for TEA are limited particularly in the case of middle-and-low-income countries; only 60 countries across the world are sampled for this survey. Similarly, the new business density, which measures formal entrepreneurship, is also limited in scope (both time and number of countries). Self-employment, although it may not connote the modern-day definition of entrepreneurship, is the most widely available proxy for all countries. It must be noted that, though self-employment data can be used across countries when collected from standardized sources, they are arguably not an appropriate measure of (actual) formal entrepreneurship (see Desai, 2011) but rather a good proxy for entrepreneurial activity (Wennekers \& Thurik, 1999) and can be interpreted to some extent as a measure of entrepreneurial potential. For brevity, we dwell on selfemployment as a measure of entrepreneurial activity in this study. Table 1 below provides a summary of the descriptive statistics of the variables.

We record mean self-employment rate of $14.94 \%$ of total employment for high-income countries and $24.20 \%$ for the middle-and-low-income countries. Particularly, the results show a higher percentage of selfemployment activities in the middle-and-low-income countries than in the high-income countries. In this regard, higher ratio of self-employment indicates a higher level of necessity entrepreneurship and, therefore, a higher level of unemployment in the economy (and a lower level of relative development in general). On income inequality, the Gini coefficient of disposable income shows high inequality for middle-and-low-income countries, recording a mean of 42.22 with a minimum and maximum Gini coefficient of 23.00 and 66.90 , respectively. For $\mathrm{HI}$ countries, the Gini coefficient of income inequality shows a mean of 29.17 with a minimum (maximum) of 22.60 (38.50). Figure 1 shows the quantile plot of the Gini coefficient of disposable income. In terms of innovation, the results show a mean of 0.56 for $\mathrm{HI}$ countries and a mean of -0.19 for $\mathrm{MLI}$ countries. For capital per worker, a mean of 0.35 is recorded for $\mathrm{HI}$ countries and 0.07 for MLI countries. Also, the results show higher GDP per capita in $\mathrm{HI}$ countries (US\$ 38,007.37) compared with a mean of US\$3,462.66 for the MLI countries. Similarly, government spending (measured by government final consumption expenditure) is high (19.71\%) in $\mathrm{HI}$ countries compared with (13.77\%) in MLI countries. We report a mean of $3.14(-1.36)$ for HI countries (MLI countries) for institutional quality. 


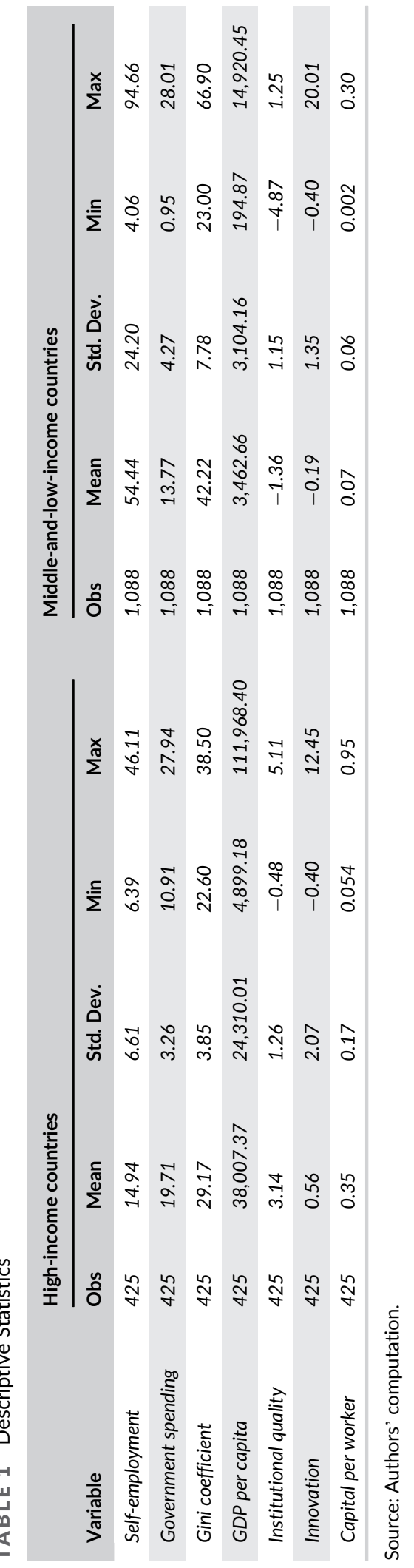



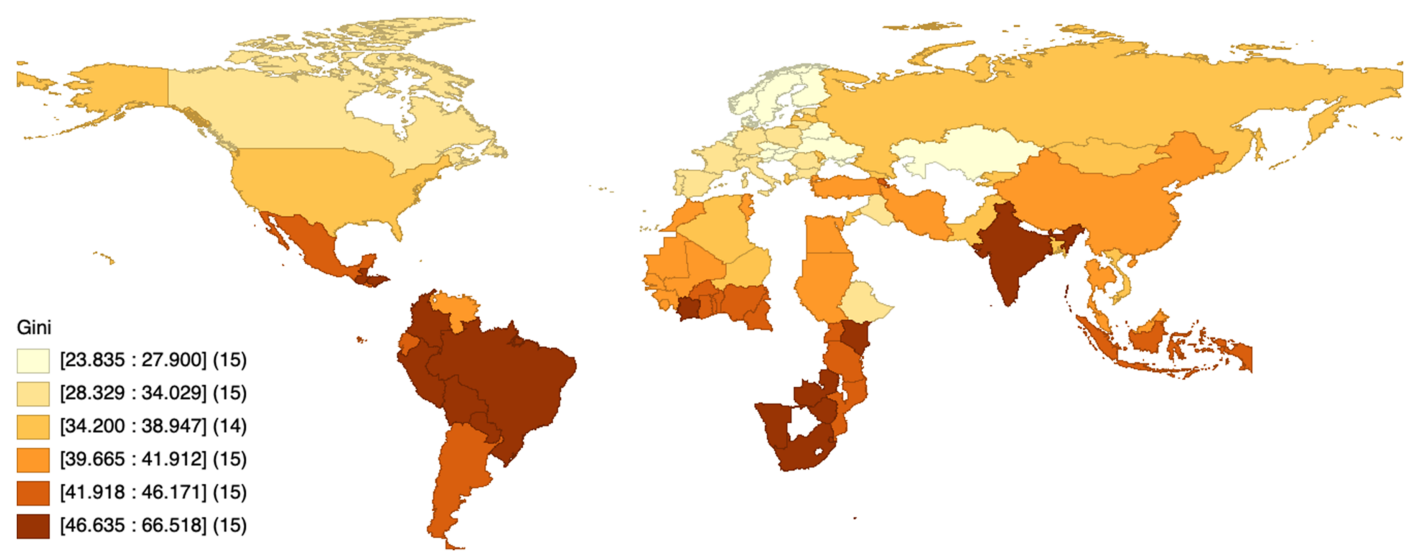

FIGURE 1 Quantile plot of average Gini coefficient of disposable, 2000-2016

\subsection{Econometric model}

To test our hypotheses, a neoclassical growth model based on a variant of the Cobb-Douglas production function with constant return to scale is used (see Wong et al., 2005). Entrepreneurial activity and innovation are entered explicitly as exogenous determinants of income. In this formulation, new firm creation and innovation may be considered as augmenting factors of production, with innovation representing knowledge capital and new firm creation representing a form of entrepreneurial capital. The Cobb-Douglas production function for cross-section is derived as follows:

$$
Y=A^{0} K^{\alpha} L^{\beta},
$$

where $Y$ is output or income; $A^{0}$ is disembodied factor productivity; $K$ is stock of physical capital; and $L$ is labor employed.

$$
y=A^{0} K^{\alpha} L^{\beta-1} .
$$

Multiplying the right-hand side by $\frac{L^{\alpha}}{L^{\alpha}}$

$$
y=A^{0}\left(\frac{K}{L}\right)^{\alpha} L^{\alpha+\beta-1}
$$

Assuming constant returns to scale, $\alpha+\beta-1$. Hence,

$$
y=A^{0}\left(\frac{K}{L}\right)^{\alpha}
$$

Taking natural logs on both sides:

$$
\ln y=\ln A^{0}+\alpha \ln \left(\frac{K}{L}\right)
$$


Growth in disembodied factor productivity, $A^{0}$, is explained by stock of knowledge capital (innovation) and entrepreneurial activity:

$$
\ln A^{0}=\beta^{0}+\phi \text { Innov }+\lambda \mathrm{ENT},
$$

where $\beta^{0}$ is a constant; Innov is an innovation index measuring innovation; and ENT is the self-employment rate measuring entrepreneurial activity. Substituting equation 6 into 5 :

$$
\ln y=\beta^{0}+\phi \operatorname{lnnov}+\lambda \mathrm{ENT}+\alpha \ln \left(\frac{K}{L}\right) .
$$

Real income, government spending, and institutional quality are controlled for in equation 7 . The generic form of the regression model used is:

$$
\ln y=\beta^{0}+\phi \operatorname{lnnov}+\lambda \mathrm{ENT}+\alpha \ln \left(\frac{K}{L}\right)+\delta \ln (\mathrm{GDPC})+\gamma \ln (\mathrm{CGOV})+\theta \ln (\operatorname{lnstq})
$$

To examine the moderating role of institutional quality with both innovation and entrepreneurial activity in influencing income inequality, we extend equation 8 to include the interaction term. The new model is specified as follows:

$$
\ln y=\beta^{0}+\phi \operatorname{lnnov}+\lambda \mathrm{ENT}+\alpha \ln \left(\frac{K}{L}\right)+\delta \ln (\mathrm{GDPC})+\gamma \ln (\mathrm{CGOV})+\theta \operatorname{lnstq}+\tau(\operatorname{lnnov} \times \operatorname{lnstq})+ב(\mathrm{ENT} \times \operatorname{Instq})
$$

Real income is included in the model because it has been demonstrated empirically to have a moderating effect on income inequality (Law et al., 2020). Institutions are included because better institutions tend to reduce income inequality (Chong \& Gradstein, 2007; Lin \& Fu, 2016). Government spending is also controlled because it has been found to reduce income inequality through social programs.

\section{3 | Methodological Approach}

In this study, the spatial panel regression model is adopted to test our hypotheses. The spatial model addresses data with spatial dependence and temporal heterogeneity. In this paper, three of the spatial panel specifications are considered: the spatial lag model (SAR), spatial error model (SEM), and spatial Durbin model (SDM). The SAR model can be written in matrix form as:

$$
y=\rho\left(I_{T} \otimes W_{N}\right) y+X \beta+\left(l_{T} \otimes I_{N}\right) \mu+\left(I_{T} \otimes l_{N}\right) \eta+u,
$$

where $\rho$ is the SAR coefficient; $y$ is an (NT $\times 1$ ) vector of observations on the dependent variable; $X$ is an (NT $\times k$ ) matrix of observations on the nonstochastic exogenous regressors. $1_{T}$ denotes a $(T \times 1)$ column vector of ones of length $T$. The coefficient $\mu$ denotes the individual effect (or heterogeneity) for each country, and $\eta$ denotes the timeperiod effect. $i_{N}$ denotes a $(N \times 1)$ column vector of ones of length $N$. $I_{N}$ denotes an $(N \times N)$ identity matrix, and $I_{T}$ is an identity matrix of dimensions $(T \times T)$. $\otimes$ denotes the Kronecker product. The weights are extended to the entire panel as follows:

$$
W_{N T}=\left(I_{T} \otimes W_{N}\right)
$$


where $I_{T}$ denotes a $(T \times T)$ identity matrix, $\otimes$ is the Kronecker product, and $W_{N}$ is an $(N \times N)$ positive nonstochastic cross-sectional spatial weighting matrix whose diagonal elements are set to zero. Following the general convention, the weights $W_{i}$ j are standardized so that each row of the matrix $W_{N}$ sums to unity. The panel SEM is also expressed as follows:

$$
\begin{gathered}
y=X \beta+\left(l_{T} \otimes I_{N}\right) \mu+\left(I_{T} \otimes l_{N}\right) \eta+u \\
u=\lambda\left(l_{T} \otimes I_{N}\right) u+\varepsilon,
\end{gathered}
$$

where $u$ reflects the spatially autocorrelated error term and $\lambda$ denotes the coefficient on the error term. The panel SDM model extends the panel SAR model with spatially lagged independent variables, and is specified as follows:

$$
y=\delta\left(I_{T} \otimes W_{N}\right) y+X \beta+\gamma\left(I_{T} \otimes W_{N}\right) X+\left(\iota_{T} \otimes I_{N}\right) \mu+\left(I_{T} \otimes l_{N}\right) \eta+u,
$$

where the parameters are the same as before but the parameter $\gamma$ denotes a coefficient on the explanatory variables.

The SDM model can be used to check if the model is nested in a SAR model or a SEM model since the models nest dependence in both the disturbances and the dependent variable (Elhorst, 2014; LeSage \& Pace, 2009). Then, this model can be used to test the hypotheses HO: $\gamma=0$ and $\mathrm{HO}: \gamma+\delta \beta=0$. The first hypothesis examines whether the SDM model is nested in the SAR model, and the second hypothesis whether it is nested in the SEM model. Both tests follow a $\chi^{2}$ distribution with $K$ degrees of freedom. If the SAR and the SEM models are estimated separately, these tests can take the form of a likelihood ratio (LR) test in order to determine which model provides the best fit for the data (Elhorst, 2014). If these models are not estimated, the LR tests can also be complemented with Wald tests It must be noted that, if both hypotheses HO: $\gamma=0$ and HO: $\gamma+\delta \beta=0$ are rejected, then the SDM model best describes the data. On the contrary, if the first hypothesis cannot be rejected, then the SAR model best describes the data, provided that the (robust) Lagrange multiplier (LM) tests also pointed to the SAR model. Likewise, if the second hypothesis cannot be rejected, then the SEM model best describes the data, provided that the (robust) LM tests also pointed to the SEM model. Elhorst (2014) argues that, if one of these conditions is not satisfied, that is, if the (robust) LM tests point to another model than the Wald/LR tests, then the SDM model should be adopted. This is because this model generalizes both the SAR model and the SEM model. For endogeneity issues, we re-estimate the models using the Kelejian and Prucha's generalized method of moments estimator (GMM-SAR).

\section{4 | EMPIRICAL RESULTS AND DISCUSSIONS}

Here, the study presents the empirical results. Table 2 presents the results of the nonspatial regression. The estimated coefficient on self-employment conforms with expectations as the coefficients are positive for middle-andlow-income countries but negative and not significant in the case of high-income countries. The coefficient on innovation also conforms with expectations, but this coefficient is not statistically significant for middle-and-low-income countries. The coefficient on real income and government spending is consistent with expectations (see Dulani et al., 2013) and highly statistically significant. The coefficients on institutional quality and its interactive terms also conform with general expectation of the behavior of institutions in both high-income and middle-and-low-income countries.

The Moran's I statistic is positive and significant at the conventional level. This shows the presence of strong spatial interdependences, implying that countries with similar income distribution (high or low) tend to be concentrated geographically. Figure 2 illustrates the graphical representation of the Moran's I test. Due to the presence of spatial autocorrelation in the nonspatial panel model, the results may suffer from misspecification if spatial dependence exists within the data. 
TABLE 2 Results of nonspatial panel model

\begin{tabular}{|c|c|c|c|}
\hline Dependent variable: Gini coefficient & All & $\mathrm{HI}$ & MLI \\
\hline Capital stock per worker & $-0.043^{* * *}(0.010)$ & $0.167^{* *}(0.048)$ & $-1.132^{* * *}(0.125)$ \\
\hline Innovation & $0.009^{* * *}(0.003)$ & $0.151^{* * *}(0.023)$ & $0.008(0.024)$ \\
\hline Self-employment & $0.207^{* * *}(0.011)$ & $-0.027(0.026)$ & $0.122^{* * *}(0.014)$ \\
\hline GDP per capita & $0.060^{* * *}(0.008)$ & $-0.126^{* * *}(0.023)$ & $0.121^{* * *}(0.008)$ \\
\hline Government spending & $0.059^{* * *}(0.015)$ & $-0.255^{* * *}(0.029)$ & $0.105^{* * *}(0.014)$ \\
\hline Institutional quality & $-0.076^{* * *}(0.010)$ & $-0.036(0.027)$ & $0.242^{* * *}(0.024)$ \\
\hline Innovation ${ }^{*}$ institutional quality & $0.007^{* * *}(0.001)$ & $-0.036^{* * *}(0.007)$ & $-0.001(0.018)$ \\
\hline Self-employment ${ }^{*}$ Institutional quality & $0.018^{* * *}(0.003)$ & $0.018(0.008)$ & $-0.057^{* * *}(0.006)$ \\
\hline Constant & $2.175^{* * *}(0.140)$ & $5.391^{* * *}(0.271)$ & $1.772^{* * *}(0.139)$ \\
\hline Observations & 1,513 & 425 & 1,088 \\
\hline$R^{2}$ & 0.5202 & 0.5177 & 0.3966 \\
\hline F-statistic & $203.9^{* * *}$ & $55.83^{* * *}$ & $88.65^{* * *}$ \\
\hline Moran's I statistic & $5.38[0.000]$ & $10.28[0.000]$ & $8.44[0.000]$ \\
\hline LM spatial error & $28.166[0.000]$ & $10.18[0.000]$ & $66.473[0.000]$ \\
\hline LM spatial lag & $26.284[0.000]$ & $83.237[0.000]$ & $69.487[0.000]$ \\
\hline Robust LM spatial error & $4.777[0.0288]$ & $2.748[0.041]$ & $3.238[0.029]$ \\
\hline Robust LM spatial lag & 2.895 [0.089] & $13.808[0.000]$ & $7.252[0.007]$ \\
\hline
\end{tabular}

Note: All, full sample estimates; HI, high-income countries; MLI, middle-and-low-income countries. The entrepreneurship indicators are self-employment. Standard errors in parentheses.

${ }^{*} p<0.1$ denotes significance at $10 \%$ level. ${ }^{* *} p<0.05$ denotes significance at $5 \%$ level. ${ }^{* * *} p<0.01$ denotes significance at $1 \%$ level.

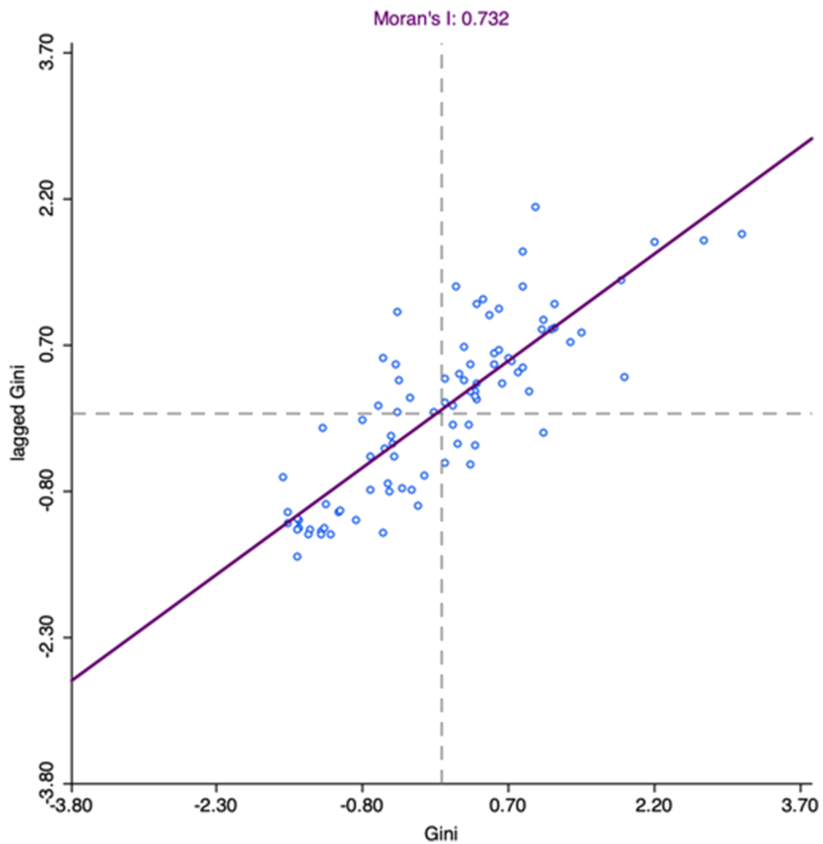

FIGURE 2 Moran's I plot of average Gini coefficient of disposable, 2000-2016 
We proceed to test for the presence of spatial dependence by conducting the classical Lagrange multiplier (LM) tests. These test results are listed in the bottom part of Table 2. From the diagnostics, the results favor the spatially autocorrelated error terms owing to consistent rejection of the hypothesis of no spatially autocorrelated error dependence. A model specification with spatially lagged dependent variable is questionable as the LM tests offer mixed results. Since the results of the classical LM test are not enough to pick the best model, a further test using the LR and Wald tests are reported to find the appropriate specification. The estimated spatial panel Durbin model is reported in Table 3.

To further test which spatial model specification is appropriate, we estimate a spatial Durbin model and then conduct likelihood ratio tests. The post-estimation test is reported in Tables 4 and 5 .

The first hypothesis ( $\mathrm{HO}: \gamma=0$ ) could not be rejected, implying that spatial lag model is the most appropriate specification. The test results indicate that the second hypothesis ( $\mathrm{HO}: \gamma+\delta \beta=0)$ could also be rejected, which implies that the SEM is not appropriate based on the results of $\mathrm{HI}$ and $\mathrm{MLI}$ but not for the overall sample. These LR and Wald test results suggest that the SDM is the most appropriate specification for this relationship. Note that the coefficients of the SDM model do not directly reflect the marginal effects of the covariates (LeSage \& Pace, 2009); hence, we interpret the results of the marginal effects presented in Tables 6-8. The direct effect shows the impact

TABLE 3 Results of spatial Durbin model (SDM)

\begin{tabular}{|c|c|c|c|}
\hline Dependent variable: Gini coefficient & All & $\mathrm{HI}$ & MLI \\
\hline Lambda $(\rho)$ & $0.140^{* * *}(0.029)$ & $0.443^{* * *}(0.039)$ & $0.229^{* * *}(0.031)$ \\
\hline Capital stock per worker & $-0.466^{* * *}(0.053)$ & $0.098^{* *}(0.039)$ & $-1.097^{* * *}(0.124)$ \\
\hline Innovation & $0.008^{* * *}(0.003)$ & $0.080^{* * *}(0.019)$ & $-0.001(0.023)$ \\
\hline Self-employment & $0.205^{* * *}(0.011)$ & $-0.005(0.022)$ & $0.130^{* * *}(0.014)$ \\
\hline GDP per capita & $0.057^{* * *}(0.008)$ & $-0.086^{* * *}(0.019)$ & $0.117^{* * *}(0.008)$ \\
\hline Government spending & $0.056^{* * *}(0.015)$ & $-0.231^{* * *}(0.026)$ & $0.118^{* * *}(0.014)$ \\
\hline Institutional quality & $-0.080^{* * *}(0.010)$ & $-0.046^{* *}(0.022)$ & $0.212^{* * *}(0.023)$ \\
\hline Innovation $\times$ Institutional quality & $0.007^{* * *}(0.001)$ & $-0.014^{* * *}(0.005)$ & $0.004(0.017)$ \\
\hline Self-employment $\times$ Institutional quality & $0.020^{* * *}(0.003)$ & $0.022^{* * *}(0.007)$ & $-0.048^{* * *}(0.006)$ \\
\hline$W \times$ Capital stock per worker & $-0.111(0.014)$ & $0.188^{* * *}(0.055)$ & $0.264^{* *}(0.170)$ \\
\hline$W \times$ Innovation & $0.008(0.005)$ & $0.079^{* * *}(0.024)$ & $-0.063(0.039)$ \\
\hline$W \times$ Self-employment & $-0.031^{* *}(0.016)$ & $0.028(0.029)$ & $-0.077^{* * *}(0.018)$ \\
\hline$W \times G D P$ per capita & $0.003(0.011)$ & $-0.044^{*}(0.024)$ & $-0.020^{*}(0.012)$ \\
\hline$W \times$ Government spending & $0.016(0.021)$ & $0.076^{* *}(0.032)$ & $\left.-0.064^{* * *} 0.019\right)$ \\
\hline$W \times$ Institutional quality & $0.031^{* *}(0.014)$ & $0.092^{* * *}(0.030)$ & $0.084^{* *}(0.033)$ \\
\hline$W \times($ Innovation $\times$ Institutional quality $)$ & $-0.0004(0.002)$ & $-0.028^{* * *}(0.007)$ & $-0.053^{*}(0.030)$ \\
\hline$W \times($ Self-employment $\times$ Institutional quality $)$ & $-0.010^{* *}(0.005)$ & $-0.030^{* * *}(0.009)$ & $-0.030^{* * *}(0.009)$ \\
\hline Constant & $1.896^{* * *}(0.170)$ & $3.442^{* * *}(0.340)$ & $1.819^{* * *}(0.175)$ \\
\hline Observations & 1,513 & 425 & 1,088 \\
\hline$R^{2}$ & 0.5357 & 0.7097 & 0.4580 \\
\hline Log likelihood & 615.50 & 509.69 & 618.79 \\
\hline AIC & -1193 & -981.38 & -1199.6 \\
\hline
\end{tabular}

Note: All, full sample estimates; HI, high-income countries; MLI, middle-and-low-income countries. The entrepreneurship indicators are self-employment. Standard errors in parentheses.

${ }^{*} p<0.1$ denotes significance at $10 \%$ level. ${ }^{* *} p<0.05$ denotes significance at $5 \%$ level. ${ }^{* * *} p<0.01$ denotes significance at $1 \%$ level. 
TAB LE 4 Post-diagnostic tests of spatial specification

\begin{tabular}{llcc} 
& All & HI & MLI \\
Wald test & & & $66.51^{* * *}$ \\
Spatial lag & $24.23^{* * *}$ & $216.95^{* * *}$ & $55.38^{* * *}$ \\
Spatial error & $24.73^{* * *}$ & $95.41^{* * *}$ & \\
LR test & & & $64.69^{* * *}$ \\
Spatial lag & $24.21^{* * *}$ & $129.6^{* * *}$ & $58.48^{* * *}$ \\
Spatial error & $25.65^{* * *}$ & $83.71^{* * *}$ & 51 \\
\hline
\end{tabular}

Note: LR tests follow a $\chi^{2}$ distribution with $K$ degrees of freedom ${ }^{*} p<0.1,{ }^{* *} p<0.05$, and ${ }^{* * *} p<0.01$.

associated with changes in the covariates on income inequality in the focal country (i). The indirect effect (spillover effect), on the other hand, shows an impact due to changes in the covariates of neighbors (j), on the income inequality of the focal country (i). The total effect is the aggregation of the direct and indirect effects. Here, it must be noted that the estimation is based on the contiguity weight matrix.

Economic interpretation of the results is based on the panel SDM model. The estimated coefficient on the spatial lagged term of income inequality $(\rho)$ is positive and highly statistically significant at the $1 \%$ level. The significant spatial autocorrelation coefficients suggest that the pattern of income inequality in neighboring countries, on average exert a positive effect on local income inequality. Since income inequality is estimated based on income/ consumption across countries, this coefficient implies that economic distance across countries affects local income distribution or vice versa. Economic distance in the high-income countries could potentially represent movement of wealth, while that of the MLI could represent movement of food commodity (if income inequality is a consumptionbased approach).

In Table 3, the regression results of the SDM model for the overall sample, $\mathrm{HI}$, and $\mathrm{MLI}$ are reported. For highincome countries (HIC), the empirical results support our hypothesis, emphasizing a positive association between innovation and income inequality $(\beta=0.080, p<0.01)$. The result of the overall sample also confirms our hypothesis $(\beta=0.008, p<0.01)$, showing that innovation is consistent and associated with more income inequality. The estimated coefficient of innovation is significant and positive, suggesting that greater innovation promotes inequality. This result is in line with evidence from Aghion et al. (2019), Piketty (2015), and Lee and Rodríguez-Pose (2013). Intuitively, the results also show the presence of trade-off between being innovative and redistribution policy. This is particularly worrisome because most country-level policies on innovation have been aligned to seek only economic growth but without addressing challenges of social injustice accompanying these innovation policies. The result can also be aligned to distortions caused by wage polarization as a result of increased usage of general-purpose technologies (Acemoglu \& Autor, 2011).

The results also show positive and statistically significant relationship between self-employment and income inequality in $\mathrm{MLI}(\beta=0.130, p<0.01)$. The implication of this finding is that high informality being a characteristic of self-employment in developing countries makes them susceptible to poverty. This is because the motive for engaging in self-employment, for many people, is not based on opportunity but out of necessity. As such, the few affluent entrepreneurs (opportunity entrepreneurs) may enjoy unconstrained wealth from their business models or innovations, particularly if they engage in cross-border entrepreneurial activities. This notwithstanding, the positive nexus may also imply that the entrepreneurial ecosystem is not receptive to entrepreneurial developments needed to increase productivity in the labor market. If only a few entrepreneurs strive for increased productivity, the gains of entrepreneurship may not spill over proportionally across all entrepreneurs and, hence, may magnify the extent of income inequality as most of the economies' wealth accrue to few. This supports evidence of prior studies that argued that entrepreneurial activities are mainly driven by rewards of their activities but not the consequence of their actions on the society. 


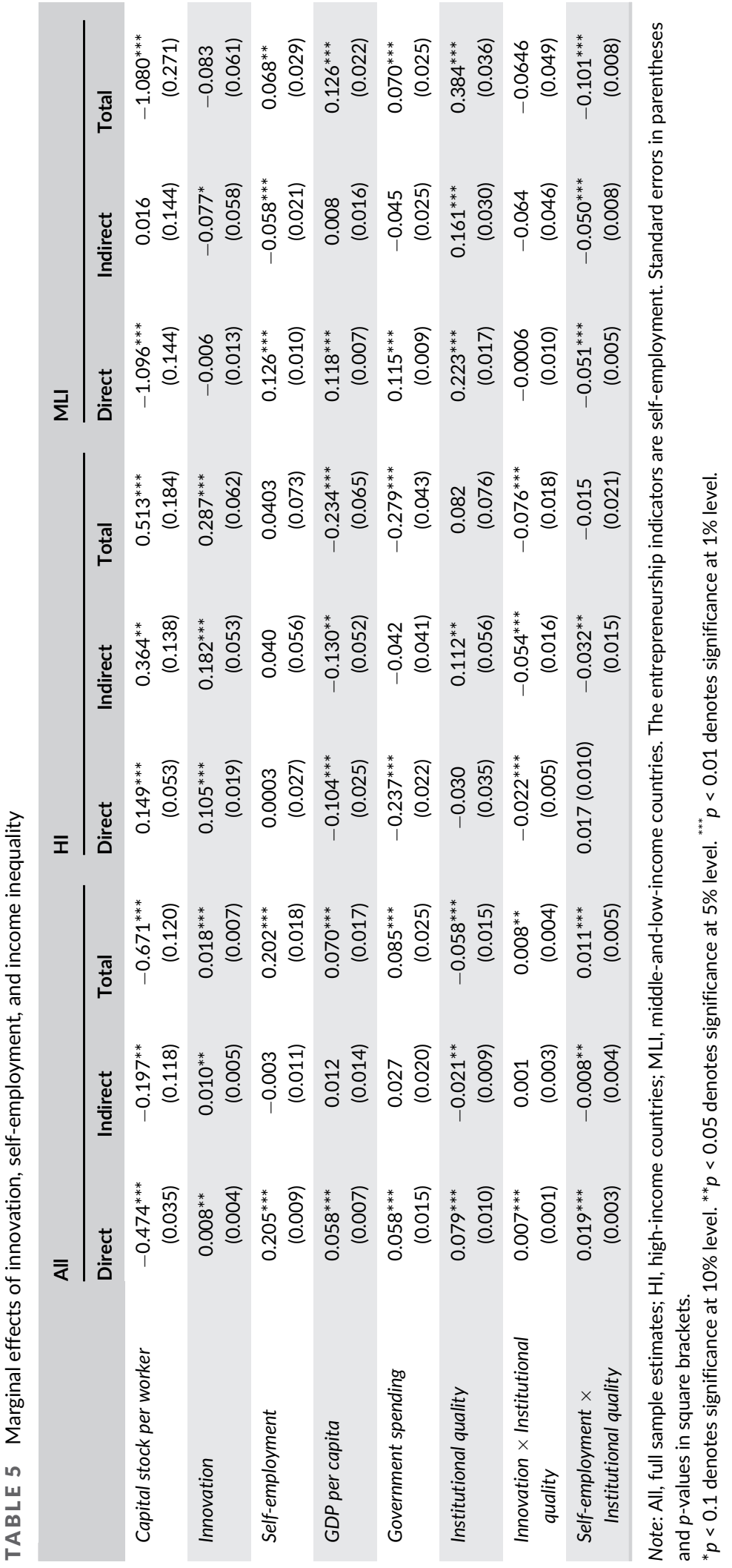


TABLE 6 Results of spatial Durbin model (SDM)

\begin{tabular}{|c|c|c|c|}
\hline Dependent variable: Gini coefficient & ALL & $\mathrm{HI}$ & MLI \\
\hline Rho $(\rho)$ & $0.153^{* * *}(0.029)$ & $0.370^{* * *}(0.042)$ & $0.309^{* * *}(0.030)$ \\
\hline Capital stock per worker & $-0.433^{* * *}(0.059)$ & $0.120^{* * *}(0.040)$ & $-1.579^{* * *}(0.138)$ \\
\hline Innovation & $0.007^{* *}(0.003)$ & $0.096^{* * *}(0.019)$ & $0.060^{* *}(0.025)$ \\
\hline Entry rate & $-0.014 *(0.007)$ & $0.014(0.023)$ & $-0.069^{* * *}(0.009)$ \\
\hline GDP per capita & $-0.018^{* *}(0.007)$ & $-0.109^{* * *}(0.019)$ & $0.068^{* * *}(0.009)$ \\
\hline Government spending & $-0.029 *(0.015)$ & $-0.228^{* * *}(0.028)$ & $0.043^{* * *}(0.015)$ \\
\hline Institutional quality & $0.002(0.005)$ & $0.014(0.016)$ & $0.081^{* * *}(0.009)$ \\
\hline Innovation $\times$ Institutional quality & $0.003^{* *}(0.001)$ & $-0.019^{* * *}(0.006)$ & $0.047^{* *}(0.019)$ \\
\hline Entry rate $\times$ Institutional quality & $-0.015^{* * *}(0.003)$ & $-0.010(0.026)$ & $-0.012^{* *}(0.006)$ \\
\hline$W \times$ Capital stock per worker & $-0.140(0.086)$ & $0.181^{* * *}(0.059)$ & $0.554^{* * *}(0.194)$ \\
\hline$W \times$ Innovation & $0.016^{* * *}(0.006)$ & $0.071^{* * *}(0.025)$ & $-0.008(0.043)$ \\
\hline $\mathrm{W} \times$ Entrepreneurial activity & $0.007(0.010)$ & $-0.010(0.026)$ & $0.039^{* * *}(0.012)$ \\
\hline$W \times G D P$ per capita & $0.019 *(0.010)$ & $-0.029(0.025)$ & $-0.026^{* *}(0.012)$ \\
\hline$W \times$ Government spending & $0.035(0.022)$ & $0.062^{*}(0.033)$ & $-0.077^{* * *}(0.019)$ \\
\hline$W \times$ Institutional quality & $-0.011^{*}(0.007)$ & $-0.006(0.017)$ & $-0.022(0.015)$ \\
\hline$W \times($ Innovation $\times$ Institutional quality $)$ & $-0.002(0.007)$ & $-0.025^{* * *}(0.007)$ & $-0.005(0.033)$ \\
\hline$W \times($ Entry rate $\times$ Institutional quality $)$ & $-0.009^{* *}(0.004)$ & $0.008(0.008)$ & $-0.005(0.008)$ \\
\hline Constant & $3.150^{* * *}(0.151)$ & $3.851^{* * *}(0.377)$ & $2.493^{* * *}(0.152)$ \\
\hline Observations & 1513 & 425 & 1088 \\
\hline$R^{2}$ & 0.4369 & 0.6821 & 0.2999 \\
\hline Log likelihood & 468.66 & 496.51 & 470.90 \\
\hline AIC & -899.32 & -955.02 & -903.8 \\
\hline
\end{tabular}

Note: All, full sample estimates; HI, high-income countries; MLI, middle-and-low-income countries. The entrepreneurship indicators are new business density (entry rate). Standard errors in parentheses.

${ }^{*} p<0.1$ denotes significance at $10 \%$ level. ${ }^{* *} p<0.05$ denotes significance at $5 \%$ level. ${ }^{* *} p<0.01$ denotes significance at $1 \%$ level.

Overall results show presence of positive dependence between self-employment and income inequality at the $1 \%$ level of significance. These findings are consistent with reviews of Desai (2011) and other studies (Atems \& Shand, 2018; Cagetti \& Nardi, 2006; Halvarsson et al., 2018; Lewellyn, 2018), who also used self-employment as a measure of entrepreneurial activity. The study further investigated the indirect channels in the role of innovation, entrepreneurial activity, and income inequality by interacting with institutional quality given the level of heterogeneity between these income groupings. The results show that the interactive term between innovation and institutional quality is negative and statistically significant, which implies that, in the presence of good institutional quality, innovation can reduce income inequality in $\mathrm{HI}$, but is only statistically significant at $10 \%$ for MLI (Table 6). For the interaction between self-employment and institutional quality, the results show positive relationship with income inequality for $\mathrm{HI}$ but negative for MLI. Thus, self-employment may provide direct employment and income distributive effects due to its more labor-intensive production and informality nature in the MLI. However, the results of the HI may be attributed to displacement effect in which some businesses may take jobs away from others owing to their newfound innovation or business model.

The coefficients of income and government spending in the MLI countries are positively correlated with income inequality. These results are consistent with the views of Dulani et al. (2013) suggesting that the impact of high 


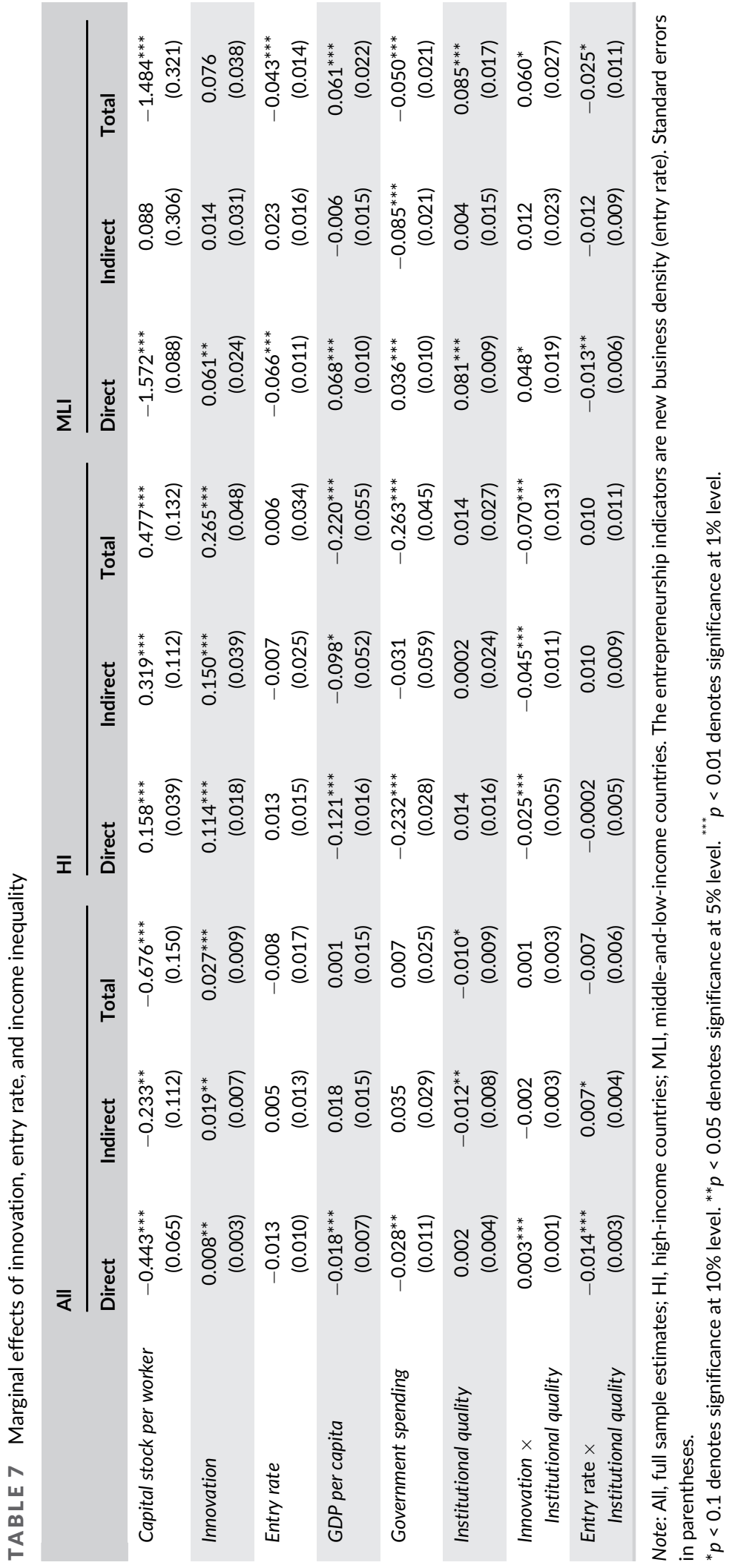


TAB LE 8 Results of spatial panel autoregressive generalized method of moments (SPGMM)

\begin{tabular}{|c|c|c|c|c|c|c|}
\hline & \multicolumn{3}{|c|}{ Self-employment } & \multicolumn{3}{|l|}{ Entry rate } \\
\hline & All & $\mathrm{HI}$ & MLIC & ALL & $\mathrm{HI}$ & MLIC \\
\hline Lag of Gini & $\begin{array}{r}0.035^{* * *} \\
(0.005)\end{array}$ & $\begin{array}{r}0.020^{* * *} \\
(0.006)\end{array}$ & $\begin{array}{r}0.011^{* * *} \\
(0.004)\end{array}$ & $\begin{array}{r}0.046^{* * *} \\
(0.006)\end{array}$ & $\begin{array}{r}0.021^{* * *} \\
(0.005)\end{array}$ & $\begin{array}{r}0.021^{* * *} \\
(0.005)\end{array}$ \\
\hline Capital stock per worker & $\begin{array}{c}-0.492^{* * *} \\
(0.055)\end{array}$ & $\begin{array}{r}0.128^{* * *} \\
(0.047)\end{array}$ & $\begin{array}{c}-0.936^{* * *} \\
(0.108)\end{array}$ & $\begin{array}{r}-0.514^{* * *} \\
(0.066)\end{array}$ & $\begin{array}{c}0.098^{* *} \\
(0.043)\end{array}$ & $\begin{array}{r}-1.419^{* * *} \\
(0.129)\end{array}$ \\
\hline Innovation & $\begin{array}{c}0.007^{* *} \\
(0.003)\end{array}$ & $\begin{array}{r}0.125^{* * *} \\
(0.026)\end{array}$ & $\begin{array}{c}-0.001 \\
(0.019)\end{array}$ & $\begin{array}{l}0.008^{* *} \\
(0.003)\end{array}$ & $\begin{array}{r}0.104^{* * *} \\
(0.022)\end{array}$ & $\begin{array}{l}0.050^{* *} \\
(0.024)\end{array}$ \\
\hline Entrepreneurial activity & $\begin{array}{r}0.196^{* * *} \\
(0.011)\end{array}$ & $\begin{array}{c}-0.017 \\
(0.026)\end{array}$ & $\begin{array}{r}0.122^{* * *} \\
(0.012)\end{array}$ & $\begin{array}{l}0.002 \\
(0.007)\end{array}$ & $\begin{array}{l}0.028 \\
(0.021)\end{array}$ & $\begin{array}{r}-0.026^{* * *} \\
(0.008)\end{array}$ \\
\hline GDP per capita & $\begin{array}{r}0.058^{* * *} \\
(0.008)\end{array}$ & $\begin{array}{r}-0.114^{* * *} \\
(0.023)\end{array}$ & $\begin{array}{r}0.107^{* * *} \\
(0.007)\end{array}$ & $\begin{array}{r}-0.015^{* *} \\
(0.007)\end{array}$ & $\begin{array}{c}-0.105^{* * *} \\
(0.021)\end{array}$ & $\begin{array}{r}0.054^{* * *} \\
(0.008)\end{array}$ \\
\hline Government spending & $\begin{array}{r}0.049^{* * *} \\
(0.015)\end{array}$ & $\begin{array}{r}-0.268^{* * *} \\
(0.029)\end{array}$ & $\begin{array}{r}0.104^{* * *} \\
(0.011)\end{array}$ & $\begin{array}{r}-0.028^{*} \\
(0.015)\end{array}$ & $\begin{array}{c}-0.251^{* * *} \\
(0.028)\end{array}$ & $\begin{array}{l}0.023^{*} \\
(0.013)\end{array}$ \\
\hline Institutional quality & $\begin{array}{c}-0.074^{* * *} \\
(0.010)\end{array}$ & $\begin{array}{r}-0.017 \\
(0.027)\end{array}$ & $\begin{array}{r}0.208^{* * *} \\
(0.021)\end{array}$ & $\begin{array}{r}-0.017^{* * *} \\
(0.004)\end{array}$ & $\begin{array}{l}0.006 \\
(0.016)\end{array}$ & $\begin{array}{r}0.068^{* * *} \\
(0.009)\end{array}$ \\
\hline $\begin{array}{l}\text { Innovation } \times \text { Institutional } \\
\text { quality }\end{array}$ & $\begin{array}{r}0.007^{* * *} \\
(0.001)\end{array}$ & $\begin{array}{r}-0.029^{* * *} \\
(0.007)\end{array}$ & $\begin{array}{l}0.0005 \\
(0.015)\end{array}$ & $\begin{array}{l}0.003^{* *} \\
(0.001)\end{array}$ & $\begin{array}{c}-0.023^{* * *} \\
(0.006)\end{array}$ & $\begin{array}{l}0.034^{* *} \\
(0.018)\end{array}$ \\
\hline $\begin{array}{l}\text { Entrepreneurial activity } \times \\
\quad \text { Institutional quality }\end{array}$ & $\begin{array}{r}0.018^{* * *} \\
(0.003)\end{array}$ & $\begin{array}{l}0.010 \\
(0.008)\end{array}$ & $\begin{array}{r}-0.045^{* * *} \\
(0.005)\end{array}$ & $\begin{array}{r}-0.002 \\
(0.003)\end{array}$ & $\begin{array}{c}-0.004 \\
(0.006)\end{array}$ & $\begin{array}{r}-0.007 \\
(0.005)\end{array}$ \\
\hline Intercept & $\begin{array}{r}2.281^{* * *} \\
(0.108)\end{array}$ & $\begin{array}{r}5.236^{* * *} \\
(0.232)\end{array}$ & $\begin{array}{r}2.228^{* * *} \\
(0.092)\end{array}$ & $\begin{array}{r}3.739^{* * *} \\
(0.069)\end{array}$ & $\begin{array}{r}5.044^{* * *} \\
(0.229)\end{array}$ & $\begin{array}{r}3.380^{* * *} \\
(0.067)\end{array}$ \\
\hline$R^{2}$ & 0.5367 & 0.5276 & 0.3922 & 0.4291 & 0.5351 & 0.1655 \\
\hline Number of observations & 1,513 & 425 & 1,088 & 1,513 & 425 & 1,088 \\
\hline
\end{tabular}

Note: All, full sample estimates; HI, high-income countries; MLI, middle-and-low-income countries. Standard errors in parentheses.

${ }^{*} p<0.1$ denotes significance at $10 \%$ level. ${ }^{* *} p<0.05$ denotes significance at $5 \%$ level. ${ }^{* *} p<0.01$ denotes significance at $1 \%$ level.

reported growth and use of public resources do not trickle down to the poorest citizens and, as such, may be worsening income inequality. That said, for incomes to reduce the inequality gap, policies that promote fair wages should be instituted to cover the poor. As expected, institutional quality is positively associated with income inequality in the $\mathrm{MLI}$ compared with the $\mathrm{HI}$ countries. These results are significant at the conventional levels. This finding for the MLI corroborates evidence of Dobson and Ramlogan (2010), Amendola et al. (2013), Perera and Lee (2013), Brunori et al. (2013), Hartmann et al. (2017), and Aiyar and Ebeke (2020), who found similar results in Latin America, Africa, and Asia. The positive relationship between institutional quality and inequality may suggest some institutional reform policies in these economies may be misguided, as argued by Andres and Ramlogan-Dobson (2011). Thus, institutional quality such as property rights, may preserve the interest of influential elites who can control key markets and access to investment opportunities and enjoy disproportionate political influence via political clientelism.

Also, contrary to Kaldor and Barro's prediction of positive relationship between investment and inequality in developing countries, the result for capital per worker is significant and negative for MLI but positive for high-income countries. It is worth noting that the coefficients of the SDM model do not directly reflect the marginal effects of the corresponding explanatory variables on the dependent variable. From a policy standpoint, the results of the nonspatial model may lead policy-makers to believe that adopting a particular policy stance, such as encouraging both innovation and entrepreneurship, will result in higher economic growth but at the expense of inequality. The direct, indirect, and total effects that represent impact due to changes in the regressors from a particular country are 
reported. The direct effect represents the impact due to changes in the regressors on the income inequality of the focal country. The indirect effect is the impact attributed to the changes in the regressors of neighboring countries on the income inequality of the focal country. The total effect is simply the aggregation of the direct and indirect effects. We can observe differences between the coefficients of the direct effect and the coefficients of the point estimates. The reason is the feedback effects that arise as a result of the impacts passing through neighboring countries and back to the countries themselves. These are due to the coefficients of the spatially lagged dependent variable and that of the spatially lagged independent regressors.

For the MLI, the direct effect of self-employment on income inequality is 0.126 and its coefficient estimate is 0.130. The lower coefficient of the estimate of the direct effect shows that self-employment and income inequality are slightly less responsive to an increase in the focal country's income inequality than what the point estimates in the SDM model shows. The direct impact shows that, if the focal country increases its self-employment by $1 \%$, then it has a positive short-run effect of $12.6 \%$ on its own income inequality. The coefficient of the direct effect suggests that a $1 \%$ increase in entrepreneurship, proxied by self-employment, will increase income inequality by $13.28 \%$. This finding corroborates evidence from Kimhi (2010) in Ethiopia, Atems and Shand (2018) in the United States, and Lewellyn (2018) for developing countries, who related the positive correlation between self-employment and income inequality but attributed it to the large informal nature of entrepreneurial activities in developing countries. The difference between the direct effect and the point estimates yields a feedback effect equal to -0.004 . The negative feedback effect shows that, over time, income inequality in the focal country will increase due to an increase in selfemployment. The indirect effect shows a spillover of -0.058 . The total effect is 0.068 . The negative spillover effect shows that entrepreneurial activities from neighboring economies have a negative effect on the focal economy. This can be possible if the entrepreneurial activity is driven mainly by a strong business sector that is linked to job creation. However, it must be noted that the indirect effect may take time to materialize; the full effects from entrepreneurial development may only be realized over the longer term, but mostly when factors that promote free movement of investment and doing business across borders are enforced (Puga, 2010). The overall sample also shows a direct effect of 0.205 that is statistically significant. The indirect effect of the interaction of self-employment and institutional quality on income inequality is negative and significant at the $5 \%$ level. Here, good institutions such as the cohesion policy may spear the reduction of disparities in the level of development (income inequality) between regions. Cross-border entrepreneurial activity of self-employment may create new market demands or capture value from existing firms, mitigating concentration of wealth in large incumbents.

On the effect of innovation on income inequality, for the high-income countries, the direct effect amounts to 0.025 and the coefficient of the point estimate from the SDM model is 0.080 . This yields a positive feedback effect of 0.102 . The indirect effect or the spillover effect is 0.182 . For MLI, the spillover effect (indirect effect) is -0.077 . For the overall sample, the direct effect equals to 0.008 while the indirect effect amounts to 0.01 . The real income per capita shows a positive feedback effect for MLIC but negative for $\mathrm{HI}$ countries. The positive feedback effects may lower income inequality over time in the focal country. This result confirms the findings of Adams (2008) and Ragoubi and El Harbi (2018). Nevertheless, the impacts of innovation and entrepreneurial activities on income inequality might vary with different settings of institutional quality. Particularly, given the lag in the institutional environment of middle- and low-income countries, profit-maximizing entrepreneurs will support mechanisms that restrict market entry and promote rent-seeking with their newfound innovations. The results show a positive feedback effect for institutional quality in MLI. The interaction effect between innovation and institutional quality has a positive feedback effect of 0.008 for $\mathrm{HI}$. MLI also recorded a positive feedback effect of 0.003 . In terms of the effect of government spending, $\mathrm{HI}$ recorded a positive feedback effect of 0.006 while $\mathrm{MLI}$ recorded a positive feedback effect of 0.003 . Feedback effects of -0.051 and -0.001 were recorded for $\mathrm{HI}$ and $\mathrm{MLI}$, respectively, for capital per worker.

For sensitivity, we replaced our measure of entrepreneurial activity (self-employment) with new business density. As a criterion of the spatial regression program (in $\mathrm{R}$ statistics), missing values are not allowed. Therefore, all missing values are replaced with zeros to balance the dataset. This is because, unlike other regression models, which 
allow unbalanced panels, the spatial regression models do not allow the use of unbalanced panels. Results of the point estimates of the SDM are presented in Table 6 and the marginal coefficients in Table 7.

For the entry rate (new business density rate), a negative feedback effect of 0.003 was recorded (Table 7), which is closer to the feedback effect recorded when self-employment is the measure of entrepreneurial activity. The signs of the control variables are qualitatively similar to the ones reported in Table 3.

In estimating the relationship between innovation, entrepreneurial activity, and income inequality, endogeneity concerns cannot be neglected. For instance, the right-hand-side variables in our model include measures of innovation, which are popularly known to be externally determined and always correlate with the error term (Aghion et al., 2019). This raises possible endogeneity concern in the econometric model and will require other estimation techniques. Conventionally, the introduction of instrumental variables would have helped in resolving this issue. However, candidate instruments must be such that they are highly correlated with the instrumented variable, but not with the error term. This poses an overburdening pressure in identifying such instruments. In view of the above-mentioned challenge, this study resolved to use the spatial panel autoregressive generalized method of moment (SPGMM) technique, which has been favored by some recent studies (e.g., Kapoor et al., 2007; Prucha, 2014). The SPGMM technique addresses issues of endogeneity by using internal instruments, which has been noted to be more efficient (Lee \& Yu, 2014). These results are consistent with our findings from the spatial Durbin estimations.

\section{5 | CONCLUSION}

This study analyzed the effect of innovation and entrepreneurial activity on income inequality in MLI countries. The authors examined the feedback and spillover effects via spatial econometric techniques using longitudinal data spanning the period 2000-2016. The study focused on middle-and-low-income countries because recent policy recommendations for these countries are aligned to the promotion of innovation and entrepreneurship. Given the exacerbated injustices of income inequality attributed to innovation and entrepreneurship in high-income countries, what will be the faith of countries climbing the ladder? The econometric methodology adopted in this study takes into account the importance of heterogeneity.

The empirical results indicated that innovation is significant in widening income inequality, especially for highincome countries. A positive innovation-inequality dependence is only possible if we measure entrepreneurial activity using World Bank's new business density (entry rate). The findings also demonstrated that the effect of entrepreneurial activity on income inequality in MLI differs depending on the proxy used. While the results show evidence of positive nexus between self-employment and income inequality, the relationship between new business density and income inequality is negative. This may be due to how each of these indicators is measured. But both measures produced a negative feedback effect, which suggested that entrepreneurial activity in the MLI may perpetuate rise in income inequality. In terms of $\mathrm{HI}$ countries, there exists no dependence between our measures of entrepreneurial activities. This study also examined whether institutional quality acts as mediator in influencing the innovation-income inequality or entrepreneurship-income inequality nexus. The findings demonstrate that institutional quality acts as mediator to reduce income inequality in $\mathrm{HI}$ when interacted with innovation, but the opposite is found in the MLI. The interaction between institutional quality and entrepreneurial activity is found to reduce income inequality in $\mathrm{MLI}$ countries. However, the findings on $\mathrm{MLI}$ are not surprising due to issues of imitation; the case of high-income countries is expected as property rights promote entrepreneurs to reap benefits from their inventions.

For policy implications, to reduce income inequality, the national wealth needs to be shared, and all talents need opportunities for innovation. To increase innovation, first, educational policy in developing countries should be leveraged to enhance science, technology, and innovation (STIs) education to achieve inclusiveness, which is crucial for economic progress, including reduction in poverty, improved healthcare, etc., which are potential drivers of income 
inequality. Also, since technological advancement is linked to productivity and sustained economic growth. Second, policies such as technology sharing policies (e.g., licensing, joint ventures, strategic alliance, etc.) should be adopted in developing countries to reduce monopoly power attributed to intellectual property rights enforceability. That said, local industries can learn to catch up with forerunners through research and development cooperation. Thus, through knowledge embeddability, elements of the forerunner's knowledge can be easily accessed by other budding entrepreneurs through interaction with the forerunner's periphery knowledge. Therefore, knowledge absorptive capability is a key element to ensure that successful catching up in developing countries reduces or dissipates the vicious cycle of wealth accumulation among few large firms. Excerpts of technology sharing policies have been adopted in South Korea, India, Indonesia, and India to scale up innovation at the rural level for productivity gains. Another possible solution to reduce income inequality in developing countries is for banking institutions to offer a market-based innovation financing for innovative and growth-oriented start-ups and small and medium-sized enterprises (SMEs). This will help the entrepreneurial poor as well as budding entrepreneurs with good business models to flourish and grow.

In addition, better institutional quality is needed to address income inequality, particularly institutions that reduce clientelism and favoritism, so that both small and medium enterprises can have equal access to resources. This will encourage individuals to create enterprises and provide attractive job opportunities. One possible solution to increase entrepreneurial activities while reducing inequality is for governments in developing countries to offer various schemes targeting the poor, especially finance. Our findings use an index of technological innovation made up of patent, grants, and trademarks; it is vital to explore other innovations such as technological upgrading in exports and innovation in services before arriving at a generalization. We leave the exploration of these possibilities to future research. Also, exploring how potential sources of research and development funding and their performing sectors influence income distribution is very relevant to advancing the literature. Using large datasets covering entrepreneurial propensity at the microlevel may further allow for the modeling of the endogenous linkage between income inequality and entrepreneurial activities over time to inform policy decisions.

\section{ORCID}

Lawrence Adu Asamoah (D) https://orcid.org/0000-0002-3193-5875

Andrea Vezzulli (D) https://orcid.org/0000-0002-2360-5112

\section{REFERENCES}

Acemoglu, D., \& Autor, D. (2011). Chapter 12 - Skills, tasks and technologies: Implications for employment and earnings. In C. David \& A. Orley (Eds.), Handbook of labor economics (Vol. 4, Part B, pp. 1043-1171). Elsevier B.V. https://doi.org/10. 1016/S0169-7218(11)02410-5

Acemoglu, D., \& Johnson, S. (2005). Unbundling institutions. Journal of Political Economy, 113(5), 949-995. https://doi.org/ $10.1086 / 432166$

Acs, Z. (2006). How is entrepreneurship good for economic growth? Innovations: Technology, Governance, Globalizations, 1(1), 97-107. https://doi.org/10.1162/itgg.2006.1.1.97

Acs, Z. J., Braunerhjelm, P., Audretsch, D. B., \& Carlsson, B. (2009). The knowledge spillover theory of entrepreneurship. Small Business Economics, 32(1), 15-30. https://doi.org/10.1007/s11187-008-9157-3

Adams, S. (2008). Globalization and income inequality: Implications for intellectual property rights. Journal of Policy Modeling, 30(5), 725-735. https://doi.org/10.1016/j.jpolmod.2007.10.005

Aghion, P., Akcigit, U., Bergeaud, A., Blundell, R., \& Hemous, D. (2019). Innovation and top income inequality. Review of Economic Studies, 86(1), 1-45. https://doi.org/10.1093/restud/rdy027

Aghion, P., \& Howitt, P. (1998). On the macroeconomic effects of major technological change. Annals of Economics and Statistics, 136(49-50), 53-75. https://doi.org/10.2307/20076110

Aiyar, S., \& Ebeke, C. (2020). Inequality of opportunity, inequality of income and economic growth. World Development, 136, 105115. https://doi.org/10.1016/j.worlddev.2020.105115

Alvaredo, F., Chancel, L., Piketty, T., Saez, E., \& Zucman, G. (2017). Global inequality dynamics: New findings from WID. world. American Economic Review, 107(5), 404-409. https://doi.org/10.1257/aer.p20171095 
Alvaredo, F., Chancel, L., Piketty, T., Saez, E., \& Zucman, G. (2018). World inequality report 2018. (1st ed., pp. 1-300). Cambridge, MA and London, England: Belknap Press. https://wir2018.wid.world/files/download/wir2018-full-reportenglish.pdf

Amendola, A., Joshy, E., \& Antonio, S. (2013). Inequality in developing economies: The role of institutional development. Public Choice, 155(1-2), 43-60Retrieved from. https://link.springer.com/content/pdf/10.1007/s11127011-9838-3.pdf

Andres, A. R., \& Ramlogan-Dobson, C. (2011). Is corruption really bad for inequality? Evidence from Latin America. Journal of Development Studies, 47(7), 959-976. https://doi.org/10.1080/00220388.2010.509784

Anselin, L. (1988). Spatial econometrics: Methods and models In Studies in operational regional science (Vol. 4, pp. 1-278). Dordrecht: Kluwer Academic.

Antonelli, C., \& Gehringer, A. (2017). Technological change, rent and income inequalities: A Schumpeterian approach. Technological Forecasting and Social Change, 115, 85-98. https://doi.org/10.1016/j.techfore.2016.09.023

Atems, B., \& Shand, G. (2018). An empirical analysis of the relationship between entrepreneurship and income inequality. Small Business Economics, 51, 905-922. https://doi.org/10.1007/s11187-017-9984-1

Azman-Saini, W. N. W., \& Hook Law, S. (2012). Institutional quality, governance, and financial development. Economics of Governance, 13(3), 217-236. https://doi.org/10.1007/s10101-012-0112-z

Benos, N. \& Tsiachtsiras, G (2019). Innovation and Inequality: World Evidence (No. 92050). Retrieved from https://mpra.ub. uni-muenchen.de/92050/

Berkowitz, D., \& Jackson, J. E. (2006). Entrepreneurship and the evolution of income distributions in Poland and Russia. Journal of Comparative Economics, 34(2), 338-356. https://doi.org/10.1016/j.jce.2006.02.003

Bloch, C. (2007). Assessing recent development in innovation measurement: The third edition of the Oslo Manual. Science and Public Policy, 34(1), 23-34. https://doi.org/10.3152/030234207X190487

Bosma, N., \& Kelley, D. (2019). Global entrepreneurship monitor 2018/2019 global report. Global Entrepreneurship Research Association (GERA).

Breau, S., Kogler, D. F., \& Bolton, K. C. (2014). On the relationship between innovation and wage inequality: New evidence from Canadian cities. Economic Geography, 90(4), 351-373. https://doi.org/10.1111/ecge.12056

Brunori, P., Ferreira, F. H. G., \& Peragine, V. (2013). Inequality of opportunity, income inequality, and economic mobility: Some international comparisons. Getting Development Right: Structural Transformation, Inclusion, and Sustainability in the Post-Crisis Era, 7155, 85-115. https://doi.org/10.1057/9781137333117_5

Bruton, G. D., Ketchen, D. J., \& Ireland, R. D. (2013). Entrepreneurship as a solution to poverty. Journal of Business Venturing, 28(6), 683-689. https://doi.org/10.1016/j.jbusvent.2013.05.002

Cagetti, M., \& Nardi, M. D. (2006). Entrepreneurship, frictions and wealth. Journal of Political Economy, 114(5), 835-870. https://doi.org/10.1086/508032

Chong, A., \& Gradstein, M. (2007). Inequality and institutions. Review of Economics and Statistics, 89(3), 454-465. https:// doi.org/10.1162/rest.89.3.454

Cozzens, S., Gatchair, S., Kang, J., Kim, K. S., Lee, H. J., Ordóñez, G., \& Porter, A. (2010). Emerging technologies: Quantitative identification and measurement. Technology Analysis and Strategic Management., 22, 361-376. https://doi.org/10.1080/ 09537321003647396

Cozzens, S. E., \& Kaplinsky, R. (2009). Innovation, poverty and inequality: Cause, coincidence, or co-evolution? In B.-Å. Lundvall, K. J. Joseph, C. Chaminade \& J. Vang (Eds.), Handbook of innovation systems and developing countries. Building domestic capabilities in a global setting (pp. 33-416). Cheltenham, United Kingdom: Edward Elgar Publishing. https://doi. org/10.4337/9781849803427

Desai, S. (2011). Measuring entrepreneurship in developing countries. In W. Naudé (Ed.), Entrepreneurship and Economic Development. Studies in Development Economics and Policy. (pp. 94-107). London: Palgrave Macmillan. https://doi. org/10.1057/9780230295155_4

Deutsch, J., \& Silber, J. (2004). Measuring the impact of various income sources on the link between inequality and development: Implications for the Kuznets curve. Review of Development Economics, 8(1), 110-127. https://doi.org/10.1111/j. 1467-9361.2004.00223.x

Dobson, S., \& Ramlogan, C. (2010). Is there a trade-off between income inequality and corruption? Evidence from Latin America. Economics Letters, 107(2), 102-104. Retrieved from. http://www.ntu.ac.uk/research/academic_schools/nbs/ working_papers/index.html, https://doi.org/10.1016/j.econlet.2009.12.038

Dulani, B., Mattes, R. B., \& Logan, C. (2013). After a decade of growth in Africa, little change in poverty at the grassroots. Cape Town: Afrobarometer.

Elhorst, J. P. (2014). Spatial panel models. In M. Fischer \& P. Nijkamp (Eds.), Handbook of regional science (1st ed., pp. 1637-1652). Berlin, Heidelberg: Springer. https://doi.org/10.1007/978-3-642-23430-9_86

Frey, C. B., \& Osborne, M. A. (2017). The future of employment: How susceptible are jobs to computerisation? Technological Forecasting and Social Change, 114, 254-280. https://doi.org/10.1016/j.techfore.2016.08.019 
Fritsch, M., \& Mueller, P. (2004). Effects of new business formation on regional development over time. Regional Studies, 38(8), 961-975. https://doi.org/10.1080/0034340042000280965

Gaddefors, J., \& Anderson, A. R. (2017). Entrepreneursheep and context: When entrepreneurship is greater than entrepreneurs. International Journal of Entrepreneurial Behavior \& Research, 23(2), 267-278. https://doi.org/10.1108/ijebr-012016-0040

Galindo, M. Á., \& Méndez-Picazo, M. T. (2013). Innovation, entrepreneurship and economic growth. Management Decision, 51(3), 501-514. https://doi.org/10.1108/00251741311309625

Halvarsson, D., Korpi, M., \& Wennberg, K. (2018). Entrepreneurship and income inequality. Journal of Economic Behavior \& Organization, 145, 275-293. https://doi.org/10.1016/j.jebo.2017.11.003

Hartmann, D., Guevara, M. R., Jara-Figueroa, C., Aristarán, M., \& Hidalgo, C. A. (2017). Linking economic complexity, institutions, and income inequality. World Development, 93, 75-93. https://doi.org/10.1016/j.worlddev.2016.12.020

Hathaway, I., Bell-Masterson, J., \& Stangler, D. (2013). The Return of Business Creation. Kauffman Foundation: SSRN Electronic Journal. http://dx.doi.org/10.2139/ssrn.2307926

Kapoor, M., Kelejian, H. H., \& Prucha, I. R. (2007). Panel data models with spatially correlated error components. Journal of Econometrics, 140(1), 97-130. https://doi.org/10.1016/j.jeconom.2006.09.004

Kaufmann, D., Kraay, A., \& Mastruzzi, M. (2011). The Worldwide Governance Indicators: Methodology and Analytical Issues. Hague Journal on the Rule of Law, 3(2), 220-246. https://doi.org/10.1017/S1876404511200046

Kimhi, A. (2010). Entrepreneurship and income inequality in southern Ethiopia. Small Business Economics, 34(1), 81-91. https://doi.org/10.1007/s11187-009-9196-4

Law, S. H., Naseem, N. A. M., Lau, W. T., \& Trinugroho, I. (2020). Can innovation improve income inequality? Evidence from panel data. Economic Systems, 44(4), 100815. https://doi.org/10.1016/j.ecosys.2020.100815

Lee, L.-f., \& Yu, J. (2014). Efficient GMM estimation of spatial dynamic panel data models with fixed effects. Journal of Econometrics, 180(2), 174-197. http://doi.org/10.1016/j.jeconom.2014.03.003

Lee, N. (2011). Are innovative regions more unequal? evidence from Europe. Environment and Planning C: Government and Policy, 29(1), 2-23. https://doi.org/10.1068/c1046r

Lee, N., \& Rodriguez-Pose, A. (2013). Innovation and spatial inequality in Europe and USA. Journal of Economic Geography, 13(1), 1-22. http://doi.org/10.1093/jeg/lbs022

LeSage, J., \& Pace, R. K. (2009). In N. Balakrishnan \& W. R. Schucany (Eds.), Introduction to spatial econometrics (Vol. 174, 1st ed., pp. 513-514). New York: Chapman and Hall/CRC. https://doi.org/10.1201/9781420064254

Lewellyn, K. B. (2018). Income Inequality, Entrepreneurial Activity, and National Business Systems: A configurational analysis. Business \& Society, 57(6), 1114-1149. http://doi.org/10.1177/0007650317697954

Lin, F., \& Fu, D. (2016). Trade, Institution Quality and Income Inequality. World Development, 77, 129-142. http://doi.org/ 10.1016/j.worlddev.2015.08.017

Lippmann, S., Davis, A., \& Aldrich, H. E. (2005). Entrepreneurship and Inequality. In L. A. Keister (Ed.), Entrepreneurship (Research in the Sociology of Work) (Vol. 15, 1st ed., pp. 3-31). Bingley: Emerald Group Publishing Limited. https://doi. org/10.1016/S0277-2833(05)15002-X

Lucas, R. E. (1988). On the mechanics of economic development. Journal of Monetary Economics, 22(1), 3-42. http://doi.org/ 10.1016/0304-3932(88)90168-7

Mohamad, N. M., Masron, T. A., \& Ibrahim, H. (2021). The role of entrepreneurship on income inequality in developing countries. Journal of Poverty, 25, 1-23. https://doi.org/10.1080/10875549.2020.1869662

Packard, M. D., \& Bylund, P. L. (2018). On the relationship between inequality and entrepreneurship. Strategic Entrepreneurship Journal, 12(1), 3-22. https://doi.org/10.1002/sej.1270

Perera, L. D. H., \& Lee, G. H. Y. (2013). Have economic growth and institutional quality contributed to poverty and inequality reduction in Asia? Journal of Asian Economics, 27, 71-86. https://doi.org/10.1016/j.asieco.2013.06.002

Piketty, T. (2015). Capital in the twenty-first century. The American Economic Review, 105(5), 48-53. https://doi.org/10. 1257/aer.p20151060

Prucha, I. R. (2014). Instrumental variables/method of moments estimation. In M. Fischer \& P. Nijkamp (Eds.), Handbook of regional science, (1st ed., pp. 1597-1617). Berlin, Heidelberg: Springer. https://doi.org/10.1007/978-3-642-234309_90

Puga, D. (2010). The magnitude and causes of agglomeration economies. Journal of Regional Science, 50(1), $203-219$. https://doi.org/10.1111/j.1467-9787.2009.00657.x

Quadrini, V. (2000). Entrepreneurship, saving, and social mobility. Review of Economic Dynamics, 3(1), 1-40. https://doi.org/ 10.1006/redy.1999.0077

Quadrini, V. (2009). Entrepreneurship in macroeconomics. Annals of Finance, 5(3-4), 295-311. https://doi.org/10.1007/ s10436-008-0105-7

Ragoubi, H., \& El Harbi, S. (2018). Entrepreneurship and income inequality: a spatial panel data analysis. International Review of Applied Economics, 32(3), 374-422. https://doi.org/10.1080/02692171.2017.1342776 
Rodríguez-Pose, A., \& Crescenzi, R. (2008). R\&D, spillovers, innovation systems and the genesis of regional growth in Europe. Regional Studies, 42(1), 51-67. https://doi.org/10.1080/00343400701654186

Romer, P. M. (1990). Endogenous technological change. Journal of Political Economy, 98(5), S71-S102. https://doi.org/10. 3386/w3210

Sampson, R. J., Jeffrey, D. M., \& Earls, F. (1999). Beyond social capital: Spatial dynamics of collective efficacy for children. American Sociological Review, 64(5), 633-660. https://doi.org/10.2307/2657367

Seo, H. J., Kim, H., \& Lee, Y. S. (2020). The dynamic relationship between inequality and sustainable economic growth. Sustainability (Switzerland), 12(14), 1-16. https://doi.org/10.3390/su12145740

Sinha, A., \& Alvarado, R. (2020). Interplay between technological innovation and environmental quality: Formulating the SDG Policies for Next 11 Economies (Vol. 242(1)) (pp. 118-549). Elsevier. Retrieved from https://www.sciencedirect.com/ science/article/pii/S0959652619334195

Stangler, D., \& Litan, R. E. (2009). Where will the jobs come from?. Kansas City, MO: Ewing Marion Kauffman. https://doi.org/ $10.2139 /$ ssrn.1580139

Stephens, H. M., \& Partridge, M. D. (2011). Do entrepreneurs enhance economic growth in lagging regions? Growth and Change, 42(4), 431-465. https://doi.org/10.1111/j.1468-2257.2011.00563.x

Stephens, H. M., Partridge, M. D., \& Faggian, A. (2013). Innovation, entrepreneurship and economic growth in lagging regions. Journal of Regional Science, 53(5), 778-812. https://doi.org/10.1111/jors.12019

Stiglitz, J. E. (2012). Macroeconomic Fluctuations, Inequality, and Human Development. Journal of Human Development and Capabilities, 13(1), 31-58. http://doi.org/10.1080/19452829.2011.643098

Tobler, W. R. (1970). A computer movie simulating urban growth in the Detroit region. Economic Geography, 46(1), 234240. https://doi.org/10.2307/143141

Usman, M., \& Hammar N. (2021). Dynamic relationship between technological innovations, financial development, renewable energy, and ecological footprint: fresh insights based on the STIRPAT model for Asia Pacific Economic Cooperation countries. Environmental Science and Pollution Research, 28(12), 15519-15536. http://doi.org/10.1007/s11356-02011640-z

Wennekers, S., \& Thurik, R. (1999). Linking entrepreneurship and economic growth. Small Business Economics, 13(1), 27-56. http://doi.org/10.1023/a:1008063200484

Wong, P. K., Ho, Y. P., \& Autio, E. (2005). Entrepreneurship, Innovation and Economic Growth: Evidence from GEM data. Small Business Economics, 24(3), 335-350. http://doi.org/10.1007/s11187-005-2000-1

How to cite this article: Asamoah, L. A., Figari, F., \& Vezzulli, A. (2021). Spillover effects of innovation and entrepreneurial activity on income inequality in developing countries: A spatial panel approach. Regional Science Policy \& Practice, 13(5), 1661-1686. https://doi.org/10.1111/rsp3.12470 
APPENDIX A: SUMMARY OF THE EXPLANATORY VARIABLES

\begin{tabular}{|c|c|c|}
\hline Variable & Description & Source \\
\hline Gini & Gini index of disposable income & SWIID 8.3 \\
\hline Innovation (innov) & $\begin{array}{l}\text { Scores from principal component analysis of patent applications, grants and } \\
\text { trademark }\end{array}$ & WIPO \\
\hline $\begin{array}{l}\text { Entrepreneurial } \\
\text { activity (ENT) }\end{array}$ & $\begin{array}{l}\text { Entrepreneurial activity is measured by self-employment and entry rate of } \\
\text { new business. Self-employment is measured as the number of self- } \\
\text { employed people (\% of total employment). Entry rate is measured as } \\
\text { number of newly registered corporations per } 1,000 \text { working-age people } \\
\text { (those ages } 15-64 \text { years) }\end{array}$ & WDI/ \\
\hline \multicolumn{3}{|l|}{ Doingbusiness.org } \\
\hline $\begin{array}{l}\text { GDP per capita } \\
\text { (GDPC) }\end{array}$ & $\begin{array}{l}\text { GDP per capita based on purchasing power parity (PPP). Data are in constant } \\
2017 \text { international dollars }\end{array}$ & WDI \\
\hline $\begin{array}{l}\text { Government } \\
\text { spending } \\
\text { (CGOV) }\end{array}$ & $\begin{array}{l}\text { General government final consumption expenditure includes all government } \\
\text { current expenditures for purchases of goods and services. Government } \\
\text { final consumption expenditure (\% of GDP) }\end{array}$ & WDI \\
\hline $\begin{array}{l}\text { Institutional } \\
\text { quality (Instq) }\end{array}$ & $\begin{array}{l}\text { The score from principal component analysis of the six governance variables } \\
\text { - control of corruption, government effectiveness, regulatory quality, rule } \\
\text { of law, voice and accountability, and political stability and absence of } \\
\text { violence/terrorism (Kaufmann et al., 2011). }\end{array}$ & WBGI \\
\hline $\begin{array}{l}\text { Capital per worker } \\
(\mathrm{K} / \mathrm{L})\end{array}$ & The ratio of capital stock to labor force & PWT 9.1/WD \\
\hline
\end{tabular}

\section{APPENDIX B: LIST OF SAMPLED COUNTRIES}

\begin{tabular}{llll} 
High-income country $(\mathbf{H I})$ & Middle-and-low-income countries (MLI) & Albania & Mozambique \\
Austria & Benin & Algeria & Namibia \\
Belgium & Bolivia & Argentina & Russian Federation \\
Canada & Brazil & Armenia & Senegal \\
Czech Republic & Bulgaria & Bangladesh & Sierra Leone \\
\hline Denmark & Burkina Faso & Cameroon & Tanzania \\
Estonia & Belarus & Ecuador & Thailand \\
\hline Finland & China & Egypt, Arab Rep. & Togo \\
France & Colombia & El Salvador & Tunisia \\
Germany & Ethiopia & Ghana & Turkey \\
Italy & Georgia & Guatemala & Uganda \\
Latvia & Poland & Guinea & Ukraine \\
Lithuania & India & &
\end{tabular}




\begin{tabular}{llll} 
High-income country (HI) & Middle-and-low-income countries (MLI) & Honduras & Pakistan \\
Luxembourg & Indonesia & Iraq & Paraguay \\
Netherlands & Iran, Islamic Rep. & Malaysia & Peru \\
Norway & Ivory Coast & Mali & South Africa \\
Portugal & Jordan & Mauritania & Sudan \\
\hline Romania & Kazakhstan & Mexico & Swaziland \\
Slovak Republic & Kenya & Moldova & Venezuela, RB \\
Slovenia & Kyrgyz Republic & Mongolia & Vietnam \\
Spain & Niger & Morocco & Zambia \\
Sweden & Nigeria & Zimbabwe & \\
Switzerland & North Macedonia & & \\
United States & & & \\
Hungary & & & \\
\hline
\end{tabular}

Note: This definition is based on World Bank new country classifications 2020. 